\title{
A B2B Team Formation Microservice for Collaborative Manufacturing in Industry $\mathbf{4 . 0}$
}

DOI:

10.1109/SERVICES.2018.00032

\section{Document Version}

Accepted author manuscript

Link to publication record in Manchester Research Explorer

\section{Citation for published version (APA):}

Cisneros Cabrera, S., Sampaio, P., \& Mehandjiev, N. (2018). A B2B Team Formation Microservice for

Collaborative Manufacturing in Industry 4.0. In 2018 IEEE World Congress on Services (SERVICES) (pp. 39-40). [8495784] (Proceedings - 2018 IEEE World Congress on Services, SERVICES 2018). IEEE.

https://doi.org/10.1109/SERVICES.2018.00032

\section{Published in:}

2018 IEEE World Congress on Services (SERVICES)

\section{Citing this paper}

Please note that where the full-text provided on Manchester Research Explorer is the Author Accepted Manuscript or Proof version this may differ from the final Published version. If citing, it is advised that you check and use the publisher's definitive version.

\section{General rights}

Copyright and moral rights for the publications made accessible in the Research Explorer are retained by the authors and/or other copyright owners and it is a condition of accessing publications that users recognise and abide by the legal requirements associated with these rights.

\section{Takedown policy}

If you believe that this document breaches copyright please refer to the University of Manchester's Takedown Procedures [http://man.ac.uk/04Y6Bo] or contact uml.scholarlycommunications@manchester.ac.uk providing relevant details, so we can investigate your claim.

\section{OPEN ACCESS}




\section{A B2B Team Formation Microservice for Collaborative Manufacturing in Industry 4.0}

\author{
Sonia Cisneros-Cabrera \\ The Alliance Manchester Business School \\ The University of Manchester \\ Manchester, United Kingdom \\ sonia.cisneroscabrera@manchester.ac.uk
}

\author{
Pedro Sampaio \\ The Alliance Manchester Business School \\ The University of Manchester \\ Manchester, United Kingdom \\ P.sampaio@manchester.ac.uk
}

\author{
Nikolay Mehandjiev \\ The Alliance Manchester Business School \\ The University of Manchester \\ Manchester, United Kingdom \\ n.mehandjiev@manchester.ac.uk
}

\begin{abstract}
Manufacturing in supply chains commonly involves collaboration between multiple and diverse enterprises forming temporary coalitions. The matchmaking and assembly of multiorganizational resources to respond to a business opportunity is a key stage in production and supply chain management, particularly in the selection of suppliers taking into account enterprises of different sizes, capabilities and marketplace reputations. Industry 4.0 technologies can have a positive impact on collaborative manufacturing by digitalizing the team formation stage, speeding-up the collaboration process, minimizing supplier risk and maximizing coalition potential. This paper proposes a microservice for team formation to facilitate collaborative manufacturing in the context of Industry 4.0, guided by Design Science research practices and involving stakeholders' vision from the automotive and aviation industries. From a technical perspective, the microservice design is conceived to facilitate interoperability with Business-to-Business (B2B) platforms.
\end{abstract}

Keywords-case studies; service-centric applications; Industry 4.0; team formation; eCollaboration; collaborative manufacturing

\section{INTRODUCTION}

We start from the premise that "old hierarchical ways of organizing work and innovation do not afford the level of agility, creativity, and connectivity that companies require to remain competitive in today's environment" [1]; this premise is valid and applicable to the manufacturing industries of the current days, particularly with the latest trends affecting industry such as "Industry 4.0" where there is a transition from existent forms of carrying out manufacturing processes to a situation in which Information and Communications Technologies (ICT) are at the core of the processes (digitalization) [2].

Among those processes, there is a growing body of literature recognizing enterprise collaborations as one of the vital processes in the supply chain $[3]-[5]$, for this, we set out to investigate what is the vision Industry 4.0 presents with regards to collaborative networks, what is the gap between current collaborative networks operation and the Industry 4.0 vision and how we can enable the Industry 4.0 collaborative networks vision.

The work presented has received funding from the European Commission under the European Union's Horizon 2020 research and innovation programme (grant agreement $n^{\circ}$ 723336). Financial support has been provided by the National Council of Science and Technology (abbreviated CONACyT) to the first author (agreement $n^{\circ}$ 461338).
In this paper, Section [II analyses the requirements for collaborations in Industry 4.0 from both the literature and industry perspectives. Section III describes the proposal of a microservice designed towards fulfilling the identified requirements, and finally, in Section IV] we discuss key research results and conclude outlining future work.

\section{Collaboration Networks IN Industry 4.0}

Guided by the research questions, we found that collaborative networks underpinning Industry 4.0 principles are envisioned to benefit from ICTs supporting an "instant" connection of geographically distant organisations, speeding-up the "get-to-know" process as well as promoting innovation and agile collaborations, and opening new markets and business opportunities reducing effort and risk-related costs [6]. To successfully implement this vision, organisations face a lack of adequate support from technologies to automate supply chain processes (See [7]), which is particularly challenging for Small and Medium Enterprises (SMEs) [2], [8]. This vision was also confirmed based on data collected from the General Manager and the Technical Director of an automotive cluster (semistructured interviews), and five manufacturing suppliers who are also members of an aviation association (focus group). Currently, the traditional face-to-face meetings they carry out on the team formation stage require a vast amount of time and effort for the involved participants, with a high risk of ending without a beneficial deal or result from the collaboration.

To address some of the identified gaps, we propose a microservice that supports team formation for collaborative manufacturing in Industry 4.0 coined as Tender Decomposition and Matchmaking Service (TDMS), intended to be a solution to support organisations joining forces to minimize the amount of effort required and to maximize the results and compounding the knowledge needed to address a manufacturing problem.

\section{Design of An Industry 4.0 Team Formation Microservice}

The TDMS facilitates the organizations' (team formation) contracting process via decomposing a Call for Tenders (CfT) into a hierarchical tree structure of tasks and product components required to fulfil the call (Tender Decomposition), and finding intersections between tree nodes derived from the 


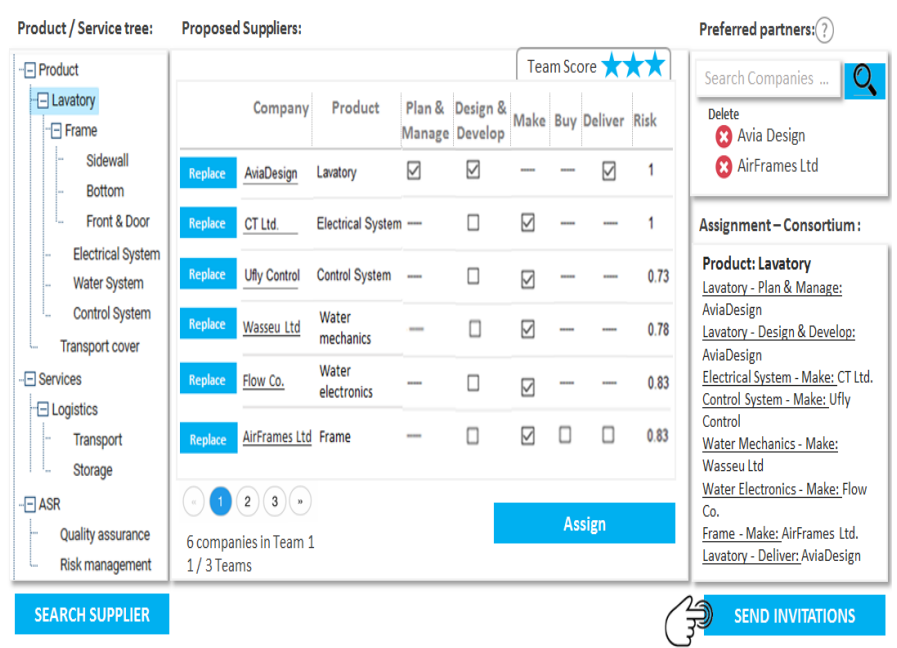

Fig. 1. TDMS user interface.

tender structure and a list of potential suppliers to deliver the required work (Matchmaking). To propose potential organisations (suppliers), these are evaluated against a number of criteria such as reliability, costs, and product quality for example, as well as considering the suitability of a partner depending on the availability of other partners in the same team; all of this in the context of the CfT at hand. Figure 1 shows how these functionalities are presented to end-users.

Technically, the design of the TDMS was conceived to provide flexibility and an independent deployment, thus, being platform-agnostic and to permit the improvement of TDMS through iterations, which is also aligned with both the Design Science methodology used for its development [9] and the microservice architecture guidelines and benefits [10]. The proposed microservice also applies Industry 4.0 design principles [11] such as information transparency, decentralization of decisions and virtual technical assistance reducing the gap towards full digitalization of manufacturing processes. We envision the TDMS as an intermediate step towards forming a virtual enterprise [12]. After using the TDMS, and handled by other microservices, the user will then be able to invite the selected companies to collaborate in the consortium and perform the respective tasks. These aspects, however, are not handled by the TDMS; we intend our microservice to be available as part of a comprehensive Business-to-business (B2B) platform to support Industry 4.0 processes (e.g. from product request to product delivery through its manufacturing processes), for which we also adopted technical designs to ease interoperability with third-party platforms and other microservices.

Finally, following the microservice principle of cohesion, we show the TDMS architecture in Figure 2, depicted as selfcontained microservice comprising two components: tender decomposition and matchmaking, where they provide two sets of functionalities but are not intended to work independently of each other.

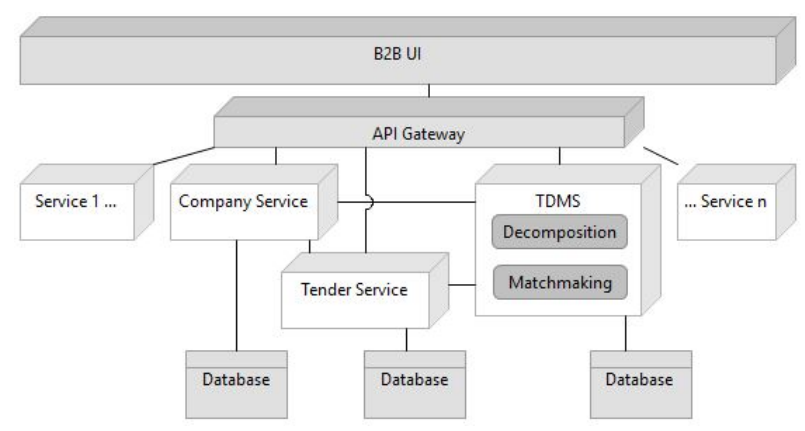

Fig. 2. TDMS architecture depicting the interaction with other microservices in a Business-to-business (B2B) platform.

\section{SUmmary AND Future WORK}

We articulated key aspects of the Industry 4.0 vision on collaborative manufacturing networks and assessed existing gaps including industry perspectives in relation to this vision. To address the gap found, we presented the design and architecture of a B2B microservice, explaining the behaviour and implications of such service. Future work will involve optimization and ranking development towards an effective decision support system, including the addition of governance and privacy rules; comprehensive end-user evaluation experiments assessing the acceptance of the proposed service, and benchmarking to assess the scalability and performance of the service. This work will also enable exploring the applicability of new collaboration models in the context of Industry 4.0.

\section{REFERENCES}

[1] N. Cook, "Enterprise 2.0 - How social software will change the future of work," International Journal of Virtual Communities and Social Networking, vol. 28, no. November, pp. 17-31, 2008.

[2] R. Geissbauer, J. Vedso, and S. Schrauf, "Industry 4.0: Building the digital enterprise," 2016 Global Industry 4.0 Survey, pp. 1-39, 2016.

[3] F. Ferreira, J. Faria, A. Azevedo, and A. L. Marques, "Industry 4.0 as enabler for effective manufacturing virtual enterprises," in Working Conference on Virtual Enterprises. Springer, 2016, pp. 274-285.

[4] A. Gunasekaran, K.-h. Lai, and T. E. Cheng, "Responsive supply chain: A competitive strategy in a networked economy," Omega, vol. 36, no. 4, pp. 549-564, August 2008.

[5] A. J. C. Trappey and D. W. Hsiao, "Applying collaborative design and modularized assembly for automotive ODM supply chain integration," Computers in Industry, vol. 59, no. 2-3, pp. 277-287, 2008.

[6] S. Sarasini, "Electrifying the automotive industry: The geography and governance of R\&D collaboration," Environmental Innovation and Societal Transitions, vol. 13, pp. 109-128, 2014.

[7] S. Cisneros-Cabrera, A. Ramzan, P. Sampaio, and N. Mehandjiev, "Digital marketplaces for Industry 4.0: A survey and gap analysis," in Working Conference on Virtual Enterprises. Springer, 2017, pp. 18-27.

[8] J. Schadel, M. Lockström, R. Moser, and N. Harrison, "Readiness for supply chain collaboration and supplier integration-findings from the chinese automotive industry," in Developments in Logistics and Supply Chain Management. Springer, 2016, pp. 125-137.

[9] A. Hevner and S. Chatterjee, "Design research in information systems," in Design Science in Information Systems, 2010, vol. 22, pp. 43-62.

[10] T. Cerny, M. J. Donahoo, and M. Trnka, "Contextual understanding of microservice architecture: current and future directions," ACM SIGAPP Applied Computing Review, vol. 17, no. 4, pp. 29-45, 2018.

[11] M. Hermann, T. Pentek, and B. Otto, "Design principles for Industrie 4.0 scenarios," in 2016 49th Hawaii International Conference on System Sciences (HICSS). IEEE, January 2016, pp. 3928-3937.

[12] N. Mehandjiev and P. Grefen, Dynamic business process formation for instant virtual enterprises. Springer, 2010. 